\title{
Activation of the mitochondria-driven pathway of apoptosis in human PC-3 prostate cancer cells by a novel hydrophilic paclitaxel derivative, 7-xylosyl-10-deacetylpaclitaxel
}

\author{
SHOUGANG JIANG ${ }^{1}$, YUANGANG ZU ${ }^{1}$, YUEJIE FU ${ }^{1}$, YU ZHANG ${ }^{1}$ and THOMAS EFFERTH ${ }^{2}$ \\ ${ }^{1}$ Key Laboratory of Foresty Plant Ecology, Ministry of Education, Northeast Forestry University, Harbin, P.R. China; \\ ${ }^{2}$ Pharmaceutical Biology, German Cancer Research Center, Heidelberg, Germany
}

Received February 19, 2008; Accepted April 8, 2008

\begin{abstract}
Paclitaxel, a natural product originally isolated from Taxus brevifolia, belongs to the most successful anticancer drugs. Nevertheless, its poor water solubility represents a considerable disadvantage in clinical use, and novel derivatives with improved pharmacological features are required. We isolated 7-xylosyl-10-deacetylpaclitaxel from Taxus chinensis, which reveals higher water solubility than paclitaxel. This compound induced mitotic cell cycle arrest and apoptosis as measured by flow cytometry, DNA laddering, and transmission electron microscopy. Pro-apoptotic Bax and Bad protein expression was up-regulated and antiapoptotic Bcl-2 and Bcl- $\mathrm{X}_{\mathrm{L}}$ expression down-regulated, which lead to a disturbance of the mitochondrial membrane permeability and to the activation of caspase-9. In turn, caspase- 9 activated downstream caspases- 3 and -6 , but not caspase-8. Bid was also activated by caspase-3. Reversely, treatment with a caspase-10-specific inhibitor could not protect PC-3 cells from 7-xylosyl-10-deacetyl-paclitaxeltriggered apoptosis. Moreover, 7-xylosyl-10-deacetylpaclitaxel had no effect on the expression of CD95 and $\mathrm{NF}-\kappa \mathrm{B}$ proteins, indicating that apoptosis was induced through the mitochondrial-dependent pathway in PC-3 cells.
\end{abstract}

\section{Introduction}

Paclitaxel was first isolated from the bark of the pacific yew (Taxus brevifolia Nutt.). It is also present in other Taxus species, e.g. T. baccata, T. chinensis, T. cruspidata (1). Paclitaxel commands a unique position among anticancer agents and pharmacologically active natural products in general $(2,3)$. After approval by the Federal Drug Admini-

Correspondence to: Dr Yuangang $\mathrm{Zu}$, Key Laboratory of Foresty Plant Ecology, Ministry of Education, Northeast Forestry University, Harbin, P.R. China

E-mail: cpu127@126.com

Key words: apoptosis, Bcl-2, caspases, cancer, chemotherapy, natural products, paclitaxel, traditional chinese medicine stration (FDA), USA, paclitaxel $\left(\right.$ Taxol $\left.^{\circledR}\right)$ has been established as a standard drug for cancer chemotherapy, especially against ovarian, breast and lung cancers. A broadening of the clinical use of paclitaxel is under investigation, i.e. for prostate cancer (4).

Paclitaxel shows a unique mechanism of action by promoting and stabilizing microtubules from tubulin (5). One of the major drawbacks of paclitaxel is its poor water solubility. Therefore, paclitaxel is usually administered by using Chremophor EL ${ }^{\circledR}$ as solvent. Although routinely applied in the clinic as a solvent for non-polar drugs, the use of Chremophor EL is not without problems. Chremophor EL is a polyoxyethylated castor oil, which causes hypersensitivity reactions (6). Considering the fact that paclitaxel itself causes severe side effects such as myelosuppression, mucositis or peripheral neuropathy, additional adverse effects caused by a solvent should be avoided (7). Synthesis of semisynthetic glycosylated taxoid derivatives is one way to improve water solubility of paclitaxel $(3,8)$. Interestingly, water soluble natural glycosylated taxoid derivatives can also be found in yew trees (9). This may provide the attractive possibility to tackle the problem of low water solubility by using naturally occurring paclitaxel derivatives.

Water decoctions from the leaves of $T$. chinensis are used in traditional Chinese medicine to treat cancer, indicating that water soluble constituents of this tree may indeed possess anticancer activity. In an effort to search for natural products from $T$. chinensis with improved pharmacological features compared to paclitaxel, 7-xylosyl-10-deacetylpaclitaxel has been isolated and identified by our group $(10,11)$. This is a naturally occurring xyloside, which has been shown to possess higher water solubility than paclitaxel $(8,12)$. Furthermore, the content of 7-xylosyl-10-deacetylpaclitaxel $(0.05 \%)$ is higher than that of paclitaxel $(0.01 \%)$ in T. chinensis (13). In fact, 7-xylosyl-10-deacetylpaclitaxel can be detected by high pressure liquid chromatography (HPLC) in condensate of decoctions $(1 \mathrm{mg} / \mathrm{ml})$, whereas paclitaxel cannot. The mode of action of 7-xylosyl-10-deacetylpaclitaxel is scarcely known. It causes polymerization and stabilization of microtubules from mammalian brain in vitro. 7-xylosyl-10deacetylpaclitaxel inhibited microtubule disassembly by $50 \%$ at a concentration of $0.3 \mu \mathrm{M}$, which is lower than that of paclitaxel $(0.5 \mu \mathrm{M})(14)$. 


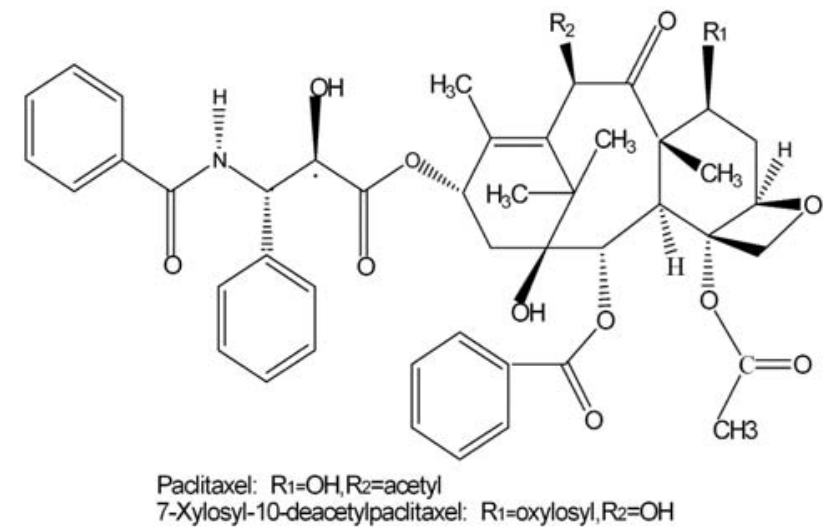

Figure 1. Chemical structures of paclitaxel and 7-xylosyl-10-deacetylpaclitaxel.

The cellular and molecular mechanisms leading to cell death after attacking microtubules by this novel paclitaxel derivative are unknown at present. For this reason, we have addressed the questions of whether 7-xylosyl-10-deacetylpaclitaxel induces cell cycle arrest and apoptosis.

\section{Materials and methods}

Chemicals. 7-xylosyl-10-deacetylpaclitaxel was isolated and identified from Taxus chinensis var. mairei Cheng et L.K by our group $(9,10)$. The extracted 7-xylosyl-10-deacetyltaxel was dissolved in dimethyl sulfoxide (Sigma Chemical Co., St. Louis, MO, USA) and stored at $4{ }^{\circ} \mathrm{C}$ (Fig. 1).

Cell line. The human PC-3 prostate cancer cell line was maintained in RPMI-1640 medium (Hyclone, Logan, USA), supplemented with $10 \%$ heat inactivated fetal calf serum (FCS), $100 \mathrm{U} / \mathrm{ml}$ penicillin and $100 \mu \mathrm{g} / \mathrm{ml}$ streptomycin in a humidified atmosphere $\left(37^{\circ} \mathrm{C}, 5 \% \mathrm{CO}_{2}\right)$.

Cytotoxicity assay. PC-3 cells were plated in 96-well plates at a density of $1 \times 10^{4}$ cells per well. After incubation with medium for $24 \mathrm{~h}, 5 \mu \mathrm{M}$ 7-xylosyl-10-deacetylpaclitaxel and paclitaxel, respectively, was applied for $48 \mathrm{~h}$. Afterwards, 3-[4,5-dimethylthiazol-2-yl]-2,5-diphenyl tetrazolium bromide (Sigma Chemical Co) was added to cell cultures at a final concentration of $0.5 \mathrm{mg} / \mathrm{ml}$ and incubated at $37^{\circ} \mathrm{C}$ for $4 \mathrm{~h}$. Then, the adherent cells were solubilized with $200 \mu 1$ DMSO. Absorbance at $492 \mathrm{~nm}$ was measured using a multi-plate reader (Stat Fax-3200, Awareness, USA). All assays were carried out in triplicate. The inhibition rate of cell proliferation was calculated by the following formula:

$$
\text { Inhibition rate }(\%)=\frac{\mathrm{OD}_{\text {control }}-\mathrm{OD}_{\text {treated }}}{\mathrm{OD}_{\text {control }}} \times 100 \%
$$

Cell cycle analysis. PC-3 cells were treated with or without $5 \mu \mathrm{M}$ 7-xylosyl-10-deacetylpaclitaxel. After incubation for $24 \mathrm{~h}$, cells were collected and stained with $50 \mu \mathrm{g} / \mathrm{ml}$ DAPI (Partec, Münster, Germany). The cell cycle distribution of 10,000 cells was collected by using a flow cytometry (Partec). Cell cycle analysis was performed using FloMax software.
Determination of apoptosis. Apoptosis was measured by Annexin-V staining (Partec) according to manufacturer's instructions. After incubation with or without $5 \mu \mathrm{M}$ 7-xylosyl10-deacetylpaclitaxel for $48 \mathrm{~h}$, cells were spun at $1200 \mathrm{x} \mathrm{g}$ for $5 \mathrm{~min}$, and the supernatant was decanted. The cell pellet was re-suspended with $100 \mu 1$ of Annexin-V binding buffer and $5 \mu \mathrm{l}$ of Annexin- $\mathrm{V}$ dye, and was left in dark at room temperature for $15 \mathrm{~min}$. Following incubation, an additional $400 \mu 1$ of Annexin-V binding buffer was added to each sample. Ten thousand cells were acquired and analyzed by flow cytometry and FloMax software (Partec).

Determination of levels of Fas (CD95). PC-3 cells were treated with 7-xylosyl-10-deacetyltaxol $(5 \mu \mathrm{M})$ for $24 \mathrm{~h}$ or left untreated. Cells were spun at $1200 \mathrm{x}$ g for $5 \mathrm{~min}$, and the supernatant was decanted. The cell pellet was re-suspended in $10 \mu \mathrm{l}$ anti-Fas (CD95) antibody (Jingmei Biotech, Shenzhen, China), and was left in dark at room temperature for $15 \mathrm{~min}$. Ten thousand cells were acquired and analyzed by flow cytometry and FloMax software (Partec).

Morphology analysis by transmission electron microscopy. PC-3 cells treated with or without $5 \mu \mathrm{M}$ 7-xylosyl-10deacetylpaclitaxel were washed with PBS, centrifuged, and pre-fixed with $2.5 \%$ glutaraldehyde in $0.1 \mathrm{M}$ phosphate buffer at $4^{\circ} \mathrm{C}$ for $2 \mathrm{~h}$. The cells were then rinsed thoroughly in phosphate buffer and post-fixed in $1 \% \mathrm{OsO}_{4}$ at $4^{\circ} \mathrm{C}$ for $30 \mathrm{~min}$. After being fixed, the cells were pelleted in $2 \%$ agar. Then, cell blocks were prepared, dehydrated through a graded ethanol series, and embedded in Epon 812 (Spi Supplies, West Chester, USA). The ultra-structure of cells was analyzed in ultra-thin sections in a transmission electron microscope (Hitachi H-600, Tokyo, Japan) after the sections were stained with uranyl acetate and lead citrate.

DNA fragmentation assay. PC-3 cells were exposed to $5 \mu \mathrm{M}$ 7-xylosyl-10-deacetylpaclitaxel for 24 and $48 \mathrm{~h}$ or left untreated. Then, cells were collected by centrifugation. Total DNA was purified with a DNA isolation kit (Waston Biotechnologies Inc, Shanghai, China) according to the manufacturer's instructions. The DNA was separated in $2 \%$ agarose gel and visualized by ultraviolet illumination (Image Mgster VDS-CL, Tokyo, Japan) after staining with ethidium bromide.

Assessment of caspase activity. The activity of caspases was determined by a colorimetric assay based on the ability of caspase-3, -6, -8 and -9 to convert acetyl-Asp-Glu-Val-Asp $p$-nitroanilide (Ac-DEVD- $p$ NA), acetyl-Val-Glu-Ile-Asp $p$-nitroanilide (Ac-VEID- $p$ NA), acetyl-Ile-Glu-Thr-Asp $p$-nitroanilide (Ac-IETD- $p$ NA) and acetyl-Leu-Glu-His-Asp $p$-nitroanilide (Ac-LEHD- $p \mathrm{NA}$ ), respectively, into a yellow formazan product [ $p$-nitroaniline $(p \mathrm{NA})]$. An increase in absorbance at $405 \mathrm{~nm}$ was used to quantify the activation of caspases. After exposure for 0, 6, 12 and 24 h, PC-3 cells were collected and rinsed with cold PBS, and then lysed by lysis buffer $(40 \mu 1)$ for $15 \mathrm{~min}$ on ice. Cell lysates were centrifuged at $18,000 \mathrm{rpm}$ for $10 \mathrm{~min}$ at $4^{\circ} \mathrm{C}$. Activities of caspase- $3,-6,-8$ and -9 in the supernatant were assayed using a commercial kit (Beyotime Institute of Biotechnology, 
Haimen, China). The caspase activities were expressed as percentage of enzyme activity compared to control. Control groups received $0.1 \%$ dimethyl sulfoxide. All the experiments were carried out in triplicate.

Protein isolation, gel electrophoresis and Western blotting. PC-3 cells were treated with 7-xylosyl-10-deacetylpaclitaxel $(5 \mu \mathrm{M})$ for $6,12,24$ and $48 \mathrm{~h}$, respectively, or left untreated. For isolation of total protein fractions, media were removed, cells were washed twice with ice-cold PBS, then lysed using cell lysis buffer [20 mM Tris pH 7.5, $150 \mathrm{mM} \mathrm{NaCl}, 1 \%$ Triton X-100, $2.5 \mathrm{mM}$ sodium pyrophosphate, $1 \mathrm{mM}$ EDTA, $1 \% \mathrm{Na}_{3} \mathrm{CO}_{4}, 0.5 \mu \mathrm{g} / \mathrm{ml}$ leupeptin, $1 \mathrm{mM}$ phenylmethanesulfonyl fluoride (PMSF)]. The lysates were collected by scraping from the plates and then centrifuged at $10,000 \mathrm{rpm}$ at $4^{\circ} \mathrm{C}$ for $5 \mathrm{~min}$.

For the investigation of mitochondrial proteins, $\mathrm{PC}-3$ cells were treated with 7-xylosyl-10-deacetylpaclitaxel $(5 \mu \mathrm{M})$ and AC-DEVD-CHO $(20 \mu \mathrm{M})$ for 6, 12, 24 and $48 \mathrm{~h}$, respectively, or left untreated. After removal of the media, PC-3 cells were washed twice with ice-cold PBS. Harvested cell suspension $\left(2 \times 10^{7}\right)$ was centrifuged in a $1.5 \mathrm{ml}$ microcentrifuge tube at $600 \mathrm{rpm}$ for $5 \mathrm{~min}$. The supernatant was carefully removed and discarded, and added $1.5 \mathrm{ml}$ of Mitochondria Isolation Reagent, vortexed at medium speed for $5 \mathrm{sec}$ in the $1.5 \mathrm{ml}$ micro-centrifuge tube and incubated the tube on ice for exactly $15 \mathrm{~min}$. The PC-3 cells suspension was transferred to a Dounce Tissue Grinder (ScieNTZ, Ningbo, China). The cells were homogenized on ice, and performed enough strokes to effectively lyse cells. Homogenized PC-3 cells were centrifuged at $600 \mathrm{rpm}$ for $10 \mathrm{~min}$ at $4^{\circ} \mathrm{C}$. The supernatant was transferred to a new $1.5 \mathrm{ml}$ tube and centrifuged at $11,000 \mathrm{rpm}$ for $15 \mathrm{~min}$ at $4^{\circ} \mathrm{C}$. The pellet contained the isolated mitochondria. Before Western blotting, $500 \mu 1$ of Mitochondria Lysis Reagent containing $1 \mathrm{mM}$ PMSF was added. Cell Mitochondria Isolation Kit (Beyotime Institute of Biotechnology).

Total protein samples for mitochondrial protein fractions (30 $\mu \mathrm{g}$ ) were loaded on a $12 \%$ of SDS-polyacrylamide gel for electrophoresis, then transferred onto PVDF transfer membranes (Millipore, Billerica, USA) at $0.8 \mathrm{~mA} / \mathrm{cm}^{2}$ for $2 \mathrm{~h}$. Membranes were blocked at room temperature for $1 \mathrm{~h}$ with blocking solution (1\% BSA in PBS plus $0.05 \%$ Tween-20). Membranes were then incubated overnight at $4^{\circ} \mathrm{C}$ with primary antibodies (anti-NF- $\mathrm{KB}$, anti- $\beta$-actin, anticaspase-3, anti-Bax, anti-Bid, anti-Bad, anti-Bcl-2, or anti$\mathrm{Bcl}-\mathrm{X}_{\mathrm{L}}$, rabbit polyclonal antibodies) at a dilution of 1:250 (Biosynthesis Biotechnology Company, Beijing, China) in blocking solution. After twice washings in PBS for each $10 \mathrm{sec}$, membranes were incubated for $1 \mathrm{~h}$ at room temperature with an alkaline phosphatase peroxidaseconjugated anti-rabbit secondary antibody at a dilution of 1:500 in blocking solution. Detection was performed by the BCIP/NBT Alkaline Phosphatase Color Development Kit (Beyotime Institute of Biotechnology) according to the manufacturer's instructions. Bands were then recorded by a digital camera (Canon, EOS 350D, Tokyo, Japan). Protein concentrations were determined using the BCA protein assay system (Beyotime Institute of Biotechnology). Caspase inhibitors, Z-AEVD-FMK and AC-DEVD-CHO,
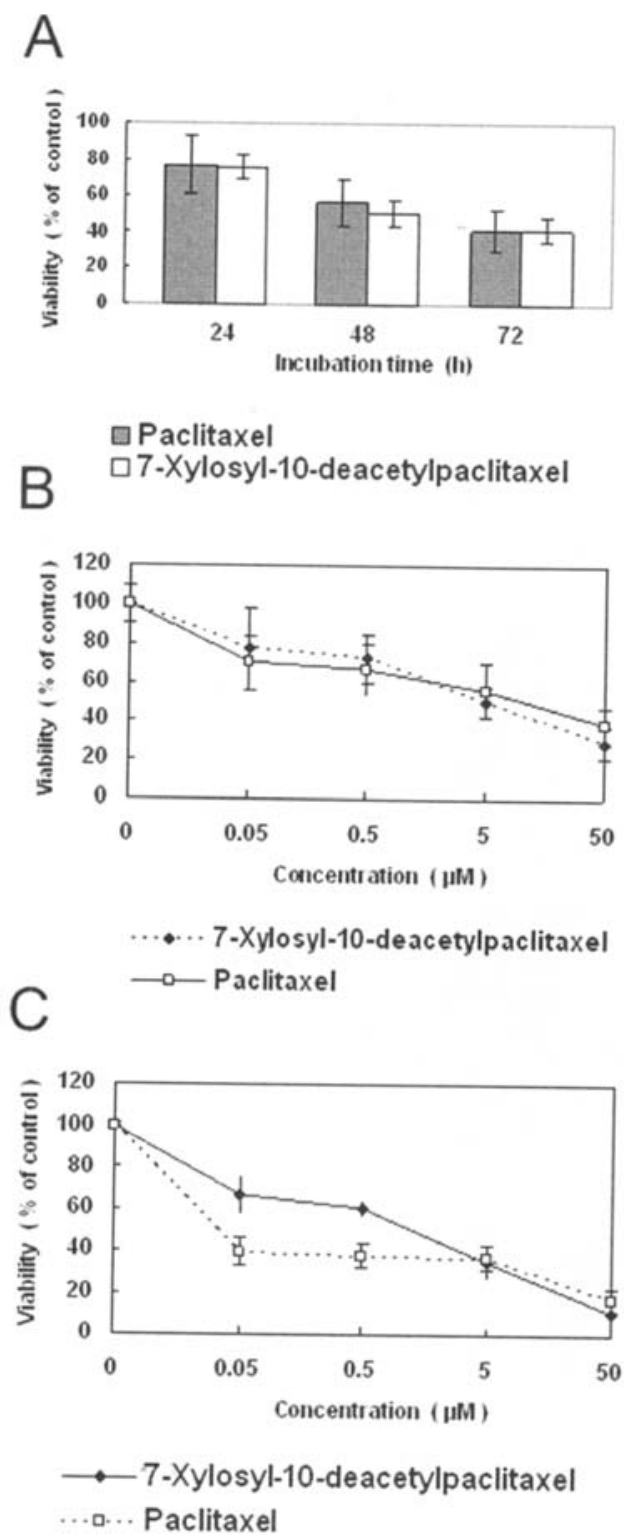

Figure 2. Cytotoxic effects of 7-xylosyl-10-deacetylpaclitaxel on PC-3 cells as measured by the MTT(3-[4,5-dimethylthiazol-2-yl]-2,5-diphenyl tetrazolium bromide) assay. (A) Time-dependent effects at a fixed concentration of $5 \mu \mathrm{M}$. (B) Concentration-dependent effects at a fixed exposure time of $48 \mathrm{~h}$. Shown are mean values $( \pm \mathrm{SD})$ of three independent experiments. (C) Concentration-dependent effects at a fixed exposure time of $72 \mathrm{~h}$. Shown are mean values $( \pm \mathrm{SD})$ of three independent experiments.

were obtained from Biovision (Biovision, Mountain View, USA).

Statistics. Data were expressed as mean \pm standard deviation (SD) of three independent experiments and analyzed using two-way analysis of variance (ANOVA). The differences between two groups were determined using the t-test, and statistical significance was set at $\mathrm{P}<0.05$.

\section{Results}

Inhibition of cell proliferation. As a starting point, we compared 7-xylosyl-10-deacetylpaclitaxel with paclitaxel. We incubated PC-3 cells with both drugs at a fixed concentration of $5 \mu \mathrm{M}$. Fig. 2A shows that both drugs inhibited 

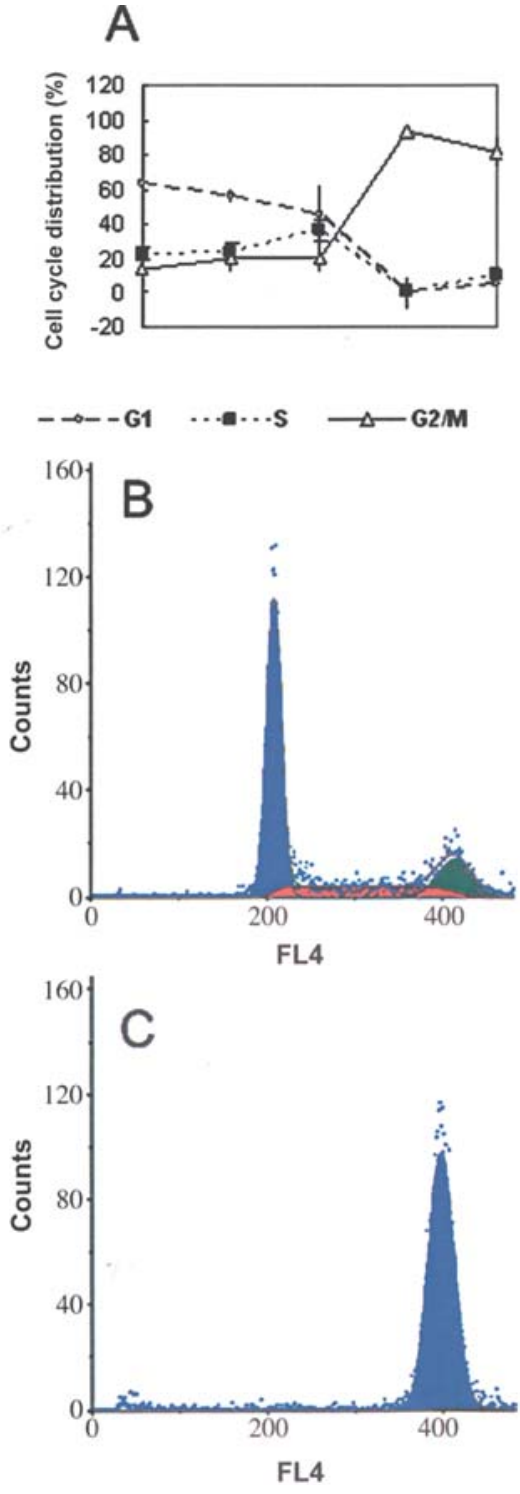

Figure 3. Cell cycle analysis of PC-3 cells treated with 7-xylosyl-10deacetylpaclitaxel as measured by DAPI-staining and flow cytometry. (A) Concentration kinetics of G2M arrest after exposure with 7-xylosyl-10deacetylpaclitaxel for $24 \mathrm{~h}$. Shown are mean values $( \pm \mathrm{SD})$ of three independent experiments. (B) Flow cytometric histogram of normal cell cycle distribution of untreated cells. (C) Flow cytometric histogram of G2M arrested cells.

PC-3 cells similarly in a time-dependent manner. To calculate $50 \%$ inhibition concentrations ( $\mathrm{IC}_{50}$ values), we performed concentration kinetic experiments. The dose response curves were in a range of $0-50 \mu \mathrm{M}$ for both drugs and are shown in Fig. 2B. The $\mathrm{IC}_{50}$ values calculated from these data were $5 \mu \mathrm{M}$ for 7-xylosyl-10-deacetylpaclitaxel and $8 \mu \mathrm{M}$ for paclitaxel at a fixed exposure time of $48 \mathrm{~h}$. And the $\mathrm{IC}_{50}$ values calculated were $586 \mathrm{nM}$ for 7-xylosyl-10-deacetylpaclitaxel and $41 \mathrm{nM}$ for paclitaxel at a fixed exposure time of $72 \mathrm{~h}$ (Fig. 2C).

Assessment of mitotic cell cycle arrest. After exposure for 24 h, 7-xylosyl-10-deacetylpaclitaxel caused a significant dose-dependent accumulation of PC-3 cells in the G2/M phase of the cell cycle and a decrease in the G1 and $\mathrm{S}$ phases
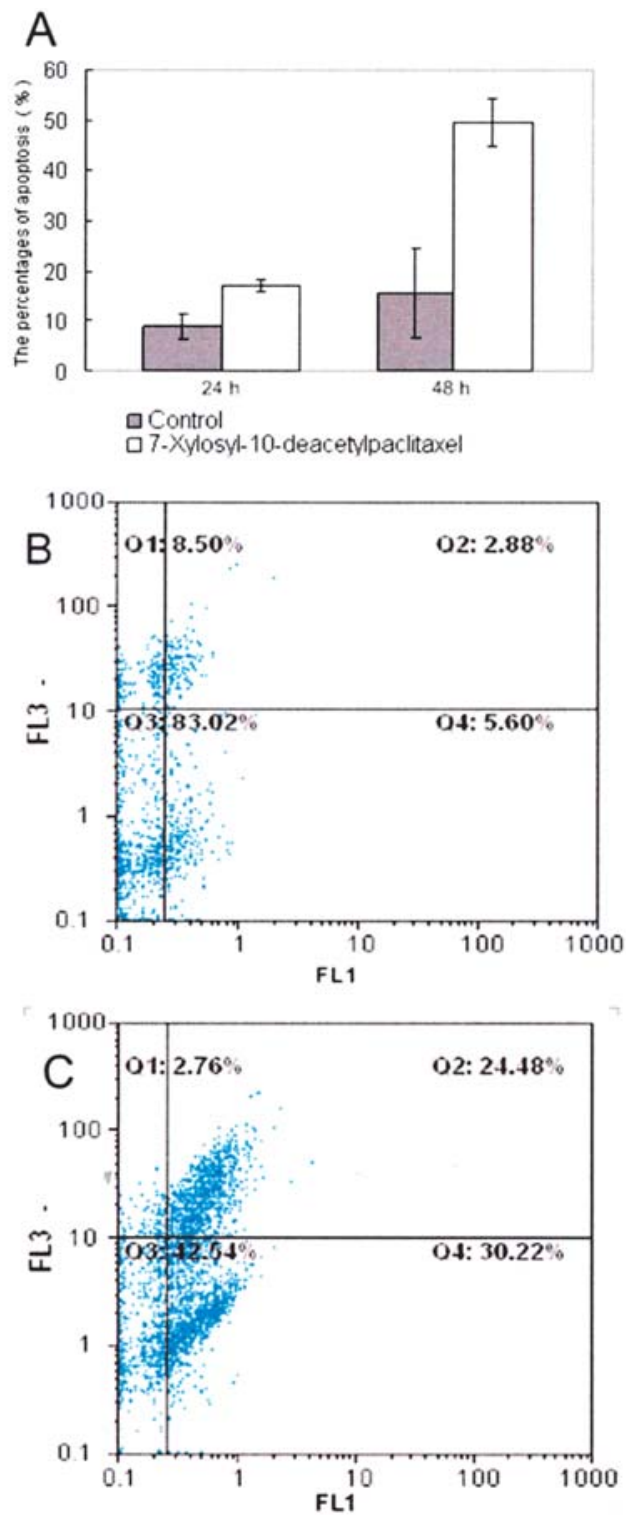

Figure 4. Induction of apoptosis in PC-3 cells treated with 7-xylosyl-10deacetylpaclitaxel as measured by PI and Annexin-V-staining and flow cytometry. (A) Percentages of apoptosis in treated and untreated cells after 24 and 48 h. (B) Flow cytometric histogram of untreated control cells (48 h). (C) Flow cytometric histogram of cells treated with $5 \mu \mathrm{M}$ 7-xylosyl-10deacetylpaclitaxel (48 h).

in a concentration range of $1 \times 10^{-7}$ to $1 \times 10^{-4} \mathrm{M}$ (Fig. 3A). The differences in cell cycle distribution between vehicle-treated PC-3 cells and cells treated with $1 \times 10^{-6}, 1 \times 10^{-5}$, or $1 \times 10^{-4} \mathrm{M}$ of the compound were statistically significant $(\mathrm{P}<0.01)$. Representative histograms showing the cell cycle distribution are depicted in Fig. 3B and C. Approximately $100 \%$ of cells treated with $1 \times 10^{-5} \mathrm{M} 7$-xylosyl-10-deacetylpaclitaxel for $24 \mathrm{~h}$ were blocked in the $\mathrm{G} 2 / \mathrm{M}$ phase (Fig. 3C), whereas only $17.3 \%$ of vehicle-treated control cells were in the G2/M phase (Fig. 3B).

Assessment of apoptosis by the Annexin $V$ assay. To quantify the induction of apoptosis, we treated PC-3 cells for 24 and $48 \mathrm{~h}$ with or without 7-xylosyl-10-deacetylpaclitaxel $(5 \mu \mathrm{M})$. Apoptosis was measured by a flow cytometry using AnnexinV labeling (Fig. 4). While 7-xylosyl-10-deacetylpaclitaxel 


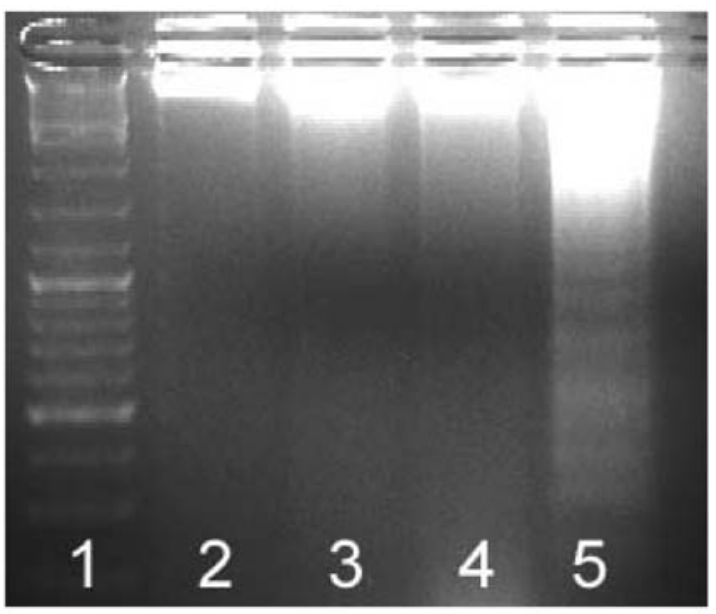

Figure 5. Assessment of apoptosis in PC-3 cells by the DNA fragmentation assay. Lane 1, DNA size marker (123-bp DNA ladder. Lanes 2 and 3, cells left untreated (lane 2) or treated with $5 \mu \mathrm{M}$ 7-xylosyl-10-deacetylpaclitaxel for $24 \mathrm{~h}$ (lane 3). Lanes 4 and 5, cells left untreated (lane 4) or treated with $5 \mu \mathrm{M}$ 7-xylosyl-10-deacetylpaclitaxel for $48 \mathrm{~h}$ (lane 5).

induced apoptosis in $17 \%$ of the cells after $24 \mathrm{~h}, 50 \%$ apoptotic cells were measured after $48 \mathrm{~h}$ (Fig. 4A). Representative flow cytometric histograms are shown in Fig. 4B and C.

Assessment of apoptosis by the DNA fragmentation assay. Treatment of PC-3 cells with $5 \mu \mathrm{M}$ 7-xylosyl-10-deacetylpaclitaxel resulted in the formation of a DNA ladder (Fig. 5). Apoptosis-related DNA laddering was visible after $48 \mathrm{~h}$ (Fig. 5, lane 5), but not after $24 \mathrm{~h}$ drug exposure (lane 3). Untreated control cells did not induce apoptosis (lanes 2 and 4).

Assessment of cellular ultrastructures by transmission electron microscopy. PC-3 cells displayed typical characteristics of apoptosis after the incubation of $5 \mu \mathrm{M} 7$-xylosyl10-deacetylpaclitaxel for $48 \mathrm{~h}$. That is, slim protuberances of the cell membrane disappeared and the structure of the membrane appeared more rigid. Vacuoles appeared in the cytoplasm (Fig. 6B). Furthermore, the nuclear membrane became unclear, the chromatin condensed and the nucleus became fragmented (Fig. 6C). These signs of apoptosis were not visible in untreated cells (Fig. 6A).

Activation of caspases. As shown in Fig. 7A, the fraction of caspase-3, -6 , and -9 positive cells increased after incubation with $5 \mu \mathrm{M}$ 7-xylosyl-10-deacetylpaclitaxel for 6 and $12 \mathrm{~h}$. However, caspase- 8 was not activated at all.

Caspase-10 is not activated by 7-xylosyl-10-deacetylpaclitaxel. Effects of caspase-10 inhibitor on 7-xylosyl-10deacetylpaclitaxel-induced apoptosis are shown in Fig. 7B. $\mathrm{PC}-3$ cells were pre-incubated in the presence or absence of $2 \mu \mathrm{M}$ caspase-10 inhibitor (Z-AEVD-FMK) for $1 \mathrm{~h}$ at $37^{\circ} \mathrm{C}$, then treated with or without $5 \mu \mathrm{M} 7$-xylosyl-10deacetylpaclitaxel for $24 \mathrm{~h}$ and processed by the Annexin- $\mathrm{V}$ assay.

Next, we confirmed this result by using Western blotting. As can be seen in Fig. 7C, PC-3 cells were pre-incubated in the presence or absence of $2 \mu \mathrm{M}$ caspase- 10 inhibitor for $1 \mathrm{~h}$ at $37^{\circ} \mathrm{C}$, and then treated with or without $5 \mu \mathrm{M} 7$-xylosyl10 -deacetylpaclitaxel for $6 \mathrm{~h}$. Caspase-10 did not activate caspase-3 in 7-xylosyl-10-deacetylpaclitaxel-treated PC-3 cells. Although PC-3 cells were pre-incubated in the presence or absence of $2 \mu \mathrm{M}$ concentrations of the inhibitor of caspases- 10 for $1 \mathrm{~h}$ at $37^{\circ} \mathrm{C}$, active caspase- 3 was identical in 7-xylosyl-10-deacetylpaclitaxel-treated PC-3 cells at $6 \mathrm{~h}$. As a positive control for this assay, we used paclitaxel (15). In contrast to paclitaxel, we found that caspase-10 did not activate caspase-3 in 7-xylosyl-10-deacetylpaclitaxel-treated cells (Fig. 7C).

Fas-dependent pathway was not involved in 7-xylosyl-10deacetylpaclitaxel-induced apoptosis. To determine whether 7-xylosyl-10-deacetylpaclitaxel induces apoptosis through activation of the extrinsic Fas receptor driven pathway of
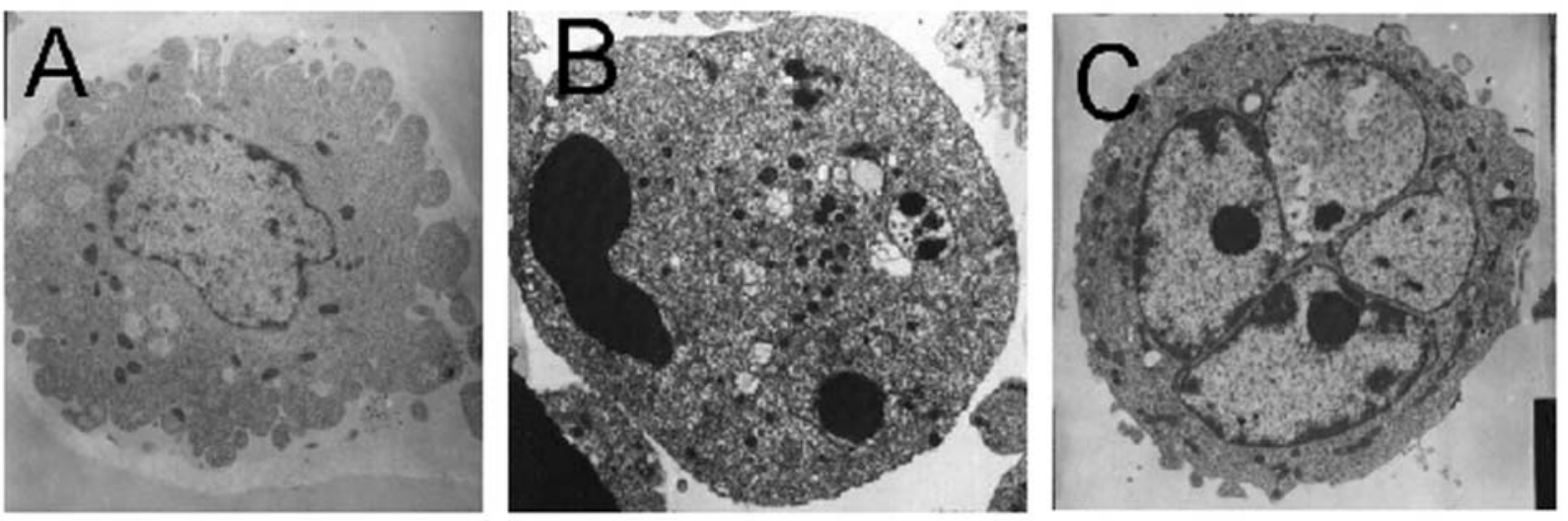

Figure 6. Assessment of ultra-structural morphology of PC-3 cells by transmission electron microscopy. (A) Untreated control cell. The nucleoli and nuclear membrane were clear. The chromatin was dispersed and not condensed. The blebs of the cell membrane indicate normal endo- and exocytotic activity. (B) Treatment with 7-xylosyl-10-deacetylpaclitaxel for $48 \mathrm{~h}$ led to a disappearance of nucleoli and a condensation of chromatin. (C) Treatment with 7-xylosyl-10deacetylpaclitaxel for $48 \mathrm{~h}$ also led to a loss of blebs in the cell membrane, to the appearance of vacuoles in the cytoplasm and a fragmentation of the nucleus. Magnification: A, x6000; B, x4000; C, x4000. 


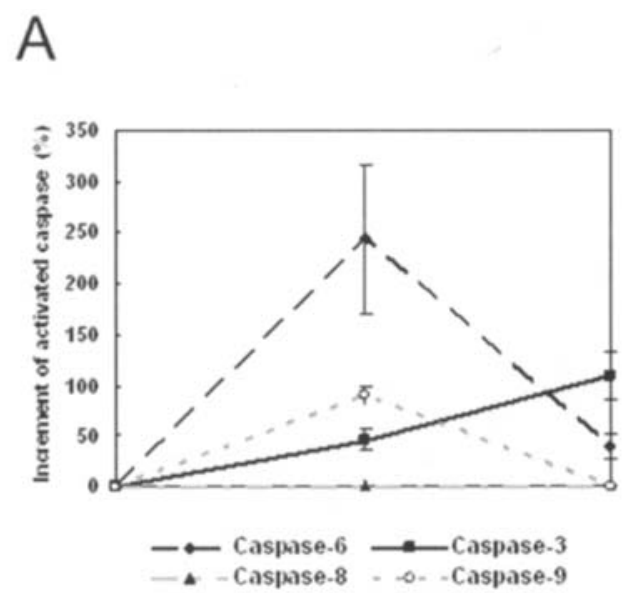

B
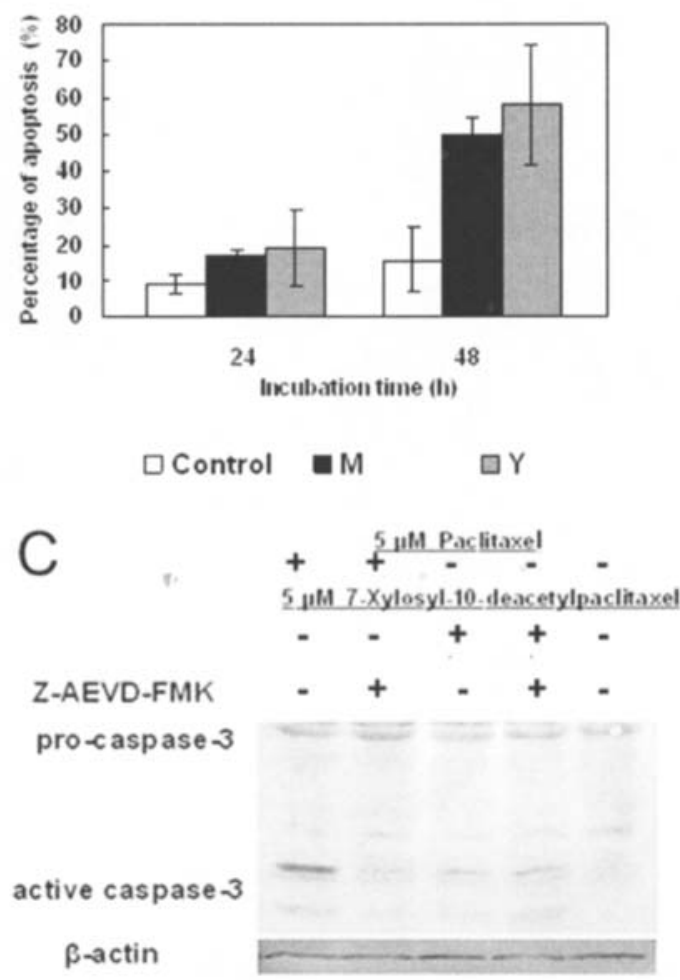

Figure 7. Role of caspases for apoptosis of PC-3 cells induced by 7-xylosyl10-deacetylpaclitaxel $(5 \mu \mathrm{M})$. (A) Colorimetric assessment of activation of caspase-3, $-6,-8,-9$. Shown are mean values $( \pm \mathrm{SD})$ of three independent experiments. (B) Effect of caspase-10 inhibitor, Z-AEVD-FMK $(2 \mu \mathrm{M})$, on 7-xylosyl-10-deacetylpaclitaxel-induced apoptosis as measured by the Annexin-V assay. M, 7-xylosyl-10-deacetylpaclitaxel alone; Y, Z-AEVDFMK plus 7-xylosyl-10-deacetylpaclitaxel. Shown are mean values $( \pm S D)$ of three independent experiments. (C) Effect of caspase-10 inhibitor, Z-AEVD-FMK $(2 \mu \mathrm{M})$, on caspase- 3 activation as assessed by Western blotting. PC-3 cells were treated for $6 \mathrm{~h}$ with 7-xylosyl-10-deacetylpaclitaxel alone or in combination with Z-AEVD-FMK. Paclitaxel served as positive control.

apoptosis, Fas (CD95) expression was measured by an anti-Fas antibody and flow cytometry. PC-3 cells cultured for $24 \mathrm{~h}$ in 7-xylosyl-10-deacetylpaclitaxel $(5 \mu \mathrm{M}) \mathrm{did}$ not reveal altered levels of Fas (CD95) (Fig. 8).

$N F-\kappa B$ is not processed in 7-xylosyl-10-deacetylpaclitaxeltreated PC-3 cells. We determined the protein levels of

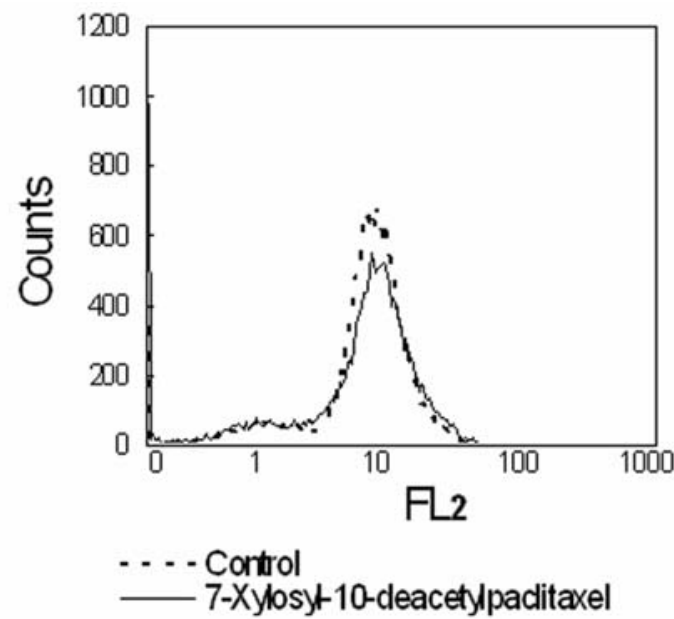

Figure 8. Effect of 7-xylosyl-10-deacetylpaclitaxel on Fas (CD95) protein expression as measured by flow cytometry.

NF- $\mathrm{B}$ in PC-3 cells treated with $5 \mu \mathrm{M}$ 7-xylosyl-10-deacetylpaclitaxel or left untreated. 7-xylosyl-10-deacetylpaclitaxelinduced apoptosis was not associated with a change in $\mathrm{NF}-\kappa \mathrm{B}$ protein expression as compared to untreated control (Fig. 9).

Regulation of expression of Bcl-2 family members by 7xylosyl-10-deacetylpaclitaxel. Apoptosis induced by $5 \mu \mathrm{M}$ 7-xylosyl-10-deacetylpaclitaxel was associated with an upregulation of $\mathrm{Bad}$ and $\mathrm{Bax}$ protein expression after treatment for 6 and $12 \mathrm{~h}$. At the same time, Bcl- $\mathrm{X}_{\mathrm{L}}$ and Bcl-2 expression were down-regulated (Fig. 9).

Bid is cleaved by caspase-3. PC-3 cells were pre-incubated in the presence or absence of $20 \mu \mathrm{M}$ caspase- 3 inhibitor, AC-DEVD-CHO, for $1 \mathrm{~h}$ at $37^{\circ} \mathrm{C}$. Then, PC-3 cells were treated with or without $5 \mu \mathrm{M}$ 7-xylosyl-10-deacetylpaclitaxel and analyzed for Bid expression by Western blotting. Bid was cleaved by caspase- 3 at 6 and 12 h [Fig. 9, Bid (Y)]. Western blotting of Bid from the mitochondrial protein fraction [Fig. 9, Bid (M)] and the protein fraction of total cells [Fig. 9, Bid (T)] did not reveal differences of expression levels between treated and untreated cells.

\section{Discussion}

In the course of our systematic analysis of bioactive natural products from water extracts of Taxus chinensis, we have isolated 7-xylosyl-10-deacetylpaclitaxel $(10,11)$. In the present investigation, we showed that 7-xylosyl-10-deacetylpaclitaxel reveals growth inhibitory activity against PC-3 cells, which is similar to that of paclitaxel at a fixed exposure time of $48 \mathrm{~h}$.

Furthermore, 7-xylosyl-10-deacetylpaclitaxel was found to induce significant mitotic arrest in PC-3 cells. Mitotic arrest was visible after $24 \mathrm{~h}$, whereas apoptosis was induced subsequently after $48 \mathrm{~h}$. This time-dependency implies that apoptosis is not induced independently of mitotic arrest. PC-3 cells run into a mitotic catastrophe, which does not lead to damage repair and re-entry of cell cycle, but rather to the induction of apoptosis. 


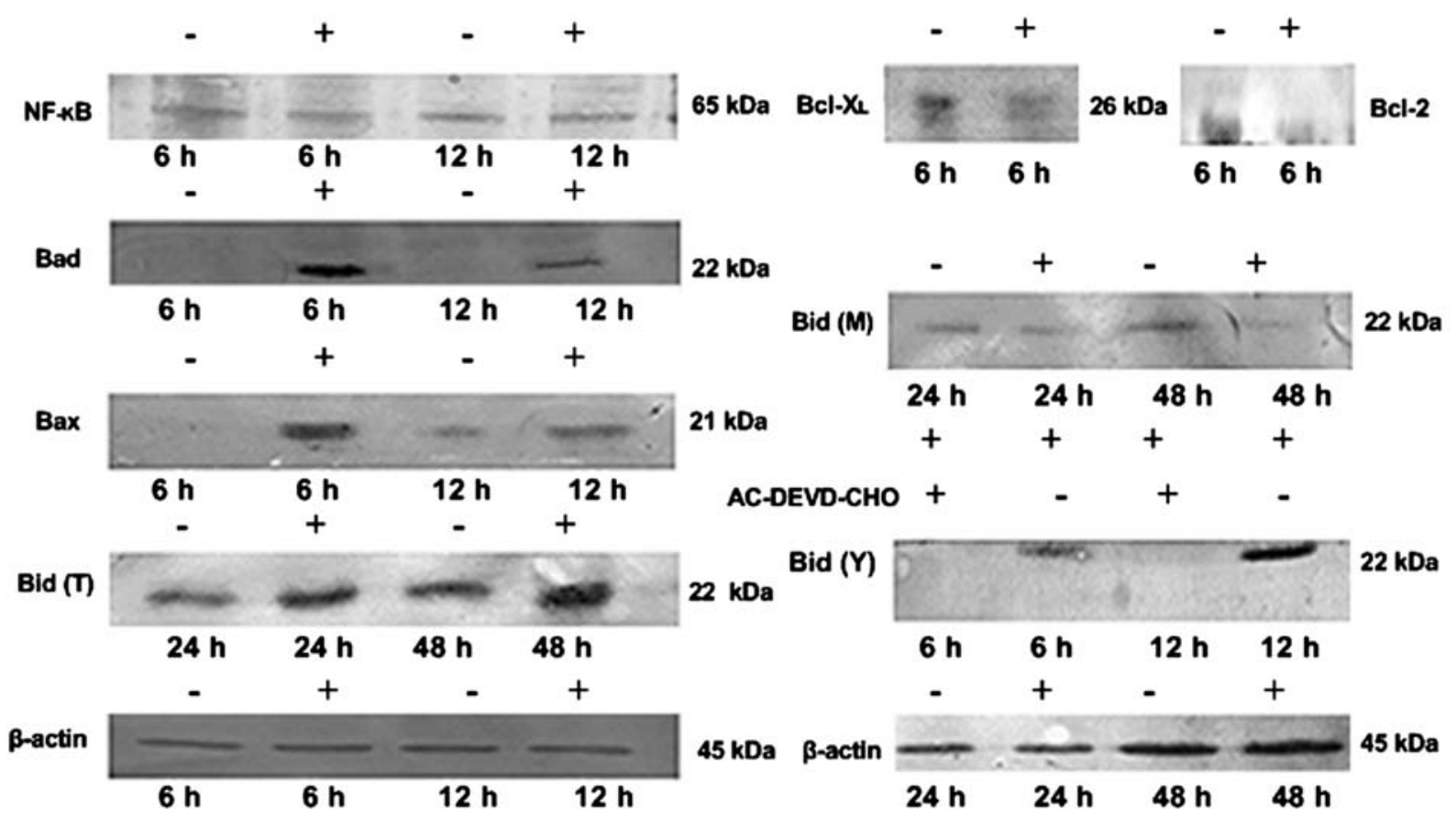

Figure 9. Effect of caspase-3 inhibitor, AC-DEVD-CHOC $(20 \mu \mathrm{M})$, on the expression of apoptosis-regulating proteins as assessed by Western blotting. Protein fractions of total cells were assessed for expression of NF- $\mathrm{B}$, Bad, Bax, and Bcl- $\mathrm{L}_{\mathrm{L}}$ after expression of 7-xylosyl-10-deacetylpaclitaxel (5 $\left.\mu \mathrm{M}\right)$. Expression of Bid was analyzed in protein factions of total cells after drug exposure for 6 and $12 \mathrm{~h}$ (T) as well as 24 and $48 \mathrm{~h}(\mathrm{Y})$, and mitochondrial protein fractions (M).

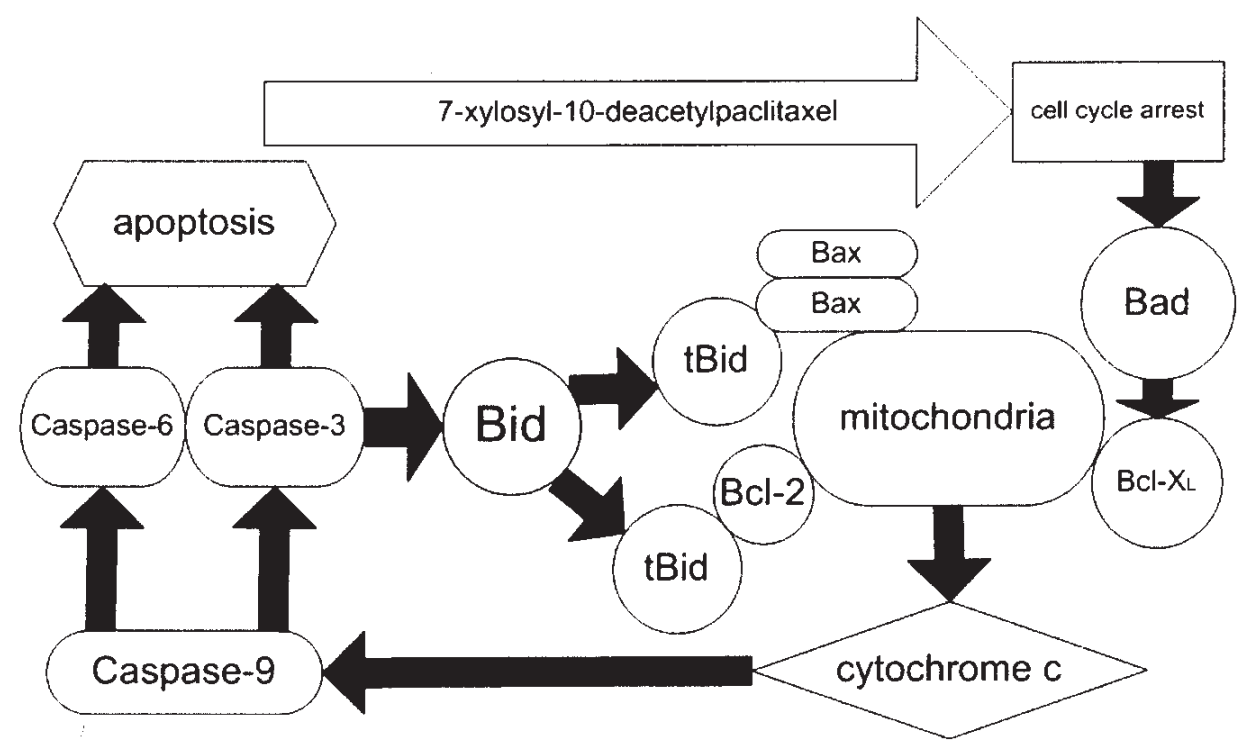

Figure 10. Signaling pathway of 7-xylosyl-10-deacetylpaclitaxel-induced apoptosis in PC-3 cells.

The results of the present study show that 7-xylosyl10-deacetylpaclitaxel-induced apoptosis is an important mechanism of cytotoxicity in PC-3 prostate cancer cells. Cellular apoptosis can be demonstrated by morphological investigations, DNA fragmentation and flow cytometry analysis. An entire battery of genes participates in the regulation of apoptosis. The activation of the caspase cascade represents a central effector mechanism promoting apoptosis in response to death-inducing signals from cell surface receptors, from mitochondria, or from endoplasmic reticular stress (16). Some studies have raised the possibility that paclitaxel might induce apoptosis through death receptors (DR4 and DR5) and caspase-8,-10 activation pathway $(17,18)$. A recent report demonstrated that activation of caspase- 8 occurs in docetaxel-treated PC-3 cells (19). However, in the present study, there was no increase in caspase- 8 activity in 7-xylosyl-10-deacetylpaclitaxel-treated PC-3 cells after exposure for 6 or $12 \mathrm{~h}$. Furthermore, PC-3 cells pretreated with a caspase-10 inhibitor did not inhibit caspase-3 activities after $6 \mathrm{~h}$ during 7-xylosyl-10-deacetylpaclitaxel-induced apoptosis $(17,20)$. The data presented here indicate that exposure of PC-3 cells to 7-xylosyl-10-deacetylpaclitaxel 
activates caspase-9. Hence, caspase-9 plays an important role in 7-xylosyl-10-deacetylpaclitaxel-mediated apoptosis. Furthermore, we observed that 7-xylosyl-10-deacetylpaclitaxel did not affect the expression of CD95 and NF-кB proteins $(21,22)$. Therefore, we conclude that 7-xylosyl-10deacetylpaclitaxel-induced apoptosis primarily involves the activation of the cytochrome c/caspase-9 pathway.

The question remains as to how caspase activation is achieved by 7-xylosyl-10-deacetylpaclitaxel treatment. The $\mathrm{Bcl}-2$ family is composed of a number of genes that control mitochondrial integrity, and loss of mitochondrial membrane potential leads to the release of apoptosis-inducing intermembrane proteins such as cytochrome c, AIF or caspase-2 and -9 (23). Recent reports demonstrated that there were no discernible differences in Bax and Bid protein expression following paclitaxel treatment $(18,24,25)$. There are, however, contradictory results in the literature on the changes of Bcl- $\mathrm{X}_{\mathrm{L}}$ expression after paclitaxel exposure $(24,25)$. In the present study, we observed significant changes in the levels of Bid, Bax, Bad and Bcl- $\mathrm{X}_{\mathrm{L}}$ proteins following 7-xylosyl10-deacetylpaclitaxel treatment, indicating that the mitochondria released inter-membrane proteins into the cytosol, which activated caspase-9. Once activated, caspase-9 initiated the caspase cascade involving downstream executioners, caspase-3 and -6 . In turn, caspase-3 cleaved and activated Bid. Activated Bid participated in a feedback loop, which may sustain and amplify cell death signal via the mitochondrial pathway by down-regulating the expression of Bcl-2 and up-regulating the expression of Bax.

In summary, 7-xylosyl-10-deacetylpaclitaxel caused significant mitotic arrest in PC-3 cells followed by a specific change in the expression profile of pro- and anti-apoptotic Bcl-2 family members. Up-regulation of Bad expression and down-regulation of $\mathrm{Bcl}-\mathrm{X}_{\mathrm{L}}$ expression are critical processes, which disturb the mitochondrial membrane permeability and activate downstream caspase-9 (26). After activation, caspase- 9 activates downstream caspase-3, -6 , and probably also caspase-7 to execute apoptosis in PC-3 cells. Meanwhile, Bid is cleaved and activated by caspase-3. At last Bid indirectly affects mitochondria membrane through upregulating the expression of Bax and down-regulating the expression of Bcl-2. Thus, the caspase- 9 zymogen plays an upstream regulatory role in the interaction of caspases. However, caspase- 8 and -10 and the Fas and TNF- $\alpha$ death receptor pathways do not seem to be involved in apoptosis induced by 7-xylosyl-10-deacetylpaclitaxel (Fig. 10) (27). Additional studies are needed to learn how 7-xylosyl-10-deacetylpaclitaxel is connected to the mitochondrial pathway and to investigate the relationship to protein kinases and signal transduction pathways.

\section{Acknowledgements}

The authors gratefully acknowledge the financial supports by National Natural Science Foundation of China (30770231), Program for New Century Excellent Talents in University (NCET-04-0316), Ministry of Education, P.R. China, the Agriculture Commercialization of Research Findings Foundation (05EFN21700432), Innovative Program for Importation of International Advanced Agricultural Science and Tech- nology, Nation Forestry Bureau (2006-4-75), Research Foundation for Science and Technology Innovation Talents of Harbin (2006RFXXS001) and Key Science Foundation of Heilongjiang Province (ZJN04-03). The author also gratefully acknowledge Mr. Yuzou Ai, Dr Liping Yao and Dr Zhonghua Zhang for technical assistance in experiments.

\section{References}

1. Nadeem M, Rikhari HC, Kumar A, Palni LMS and Nandi SK: Taxol content in the bark of Himalayan Yew in relation to tree age and sex. Phytochemistry 60: 627-631, 2002.

2. Donehower RC: The clinical development of paclitaxel: a successful collaboration of academia, industry and the National Cancer Institute. Stem Cells 14: 25-28, 1996.

3. Zefirova ON, Nurieva EV, Ryzhov AN, Zyk NV and Zefirov NS: Taxol: synthesis, bioactive conformations and structure-activity relationships in its analogs. Russ J Org Chem 41: 315-351, 2001.

4. Mancuso A, Oudard S and Sternberg CN: Effective chemotherapy for hormone-refractory prostate cancer HRPC: present status and perspectives with taxane-based treatments. Crit Rev Oncol Hemat 61: 176-185, 2007.

5. Orr GA, Verdier-Pinard P, McDaid H and Horwitz SB: Mechanisms of Taxol resistance related to microtubules. Oncogene 47: 7280-7295, 2003.

6. Bouvier E, Thirot S, Schmidt F and Monneret C: A new paclitaxel prodrug for use in ADEPT strategy. Org Biomol Chem 1: 3343-3352, 2003.

7. Slichenmyer WJ and Von Hoff DD: Taxol: a new and effective anti-cancer drug. Anticancer Drugs 2: 519-530, 1991.

8. Mandai T, Okumoto H, Oshitari T, et al: Synthesis and biological evaluation of water soluble taxoids bearing sugar moieties. Heterocycles 54: 561-566, 2001.

9. Parmar VS, Jha A, Bisht KS, et al: Constituents of the yew trees. Phytochemistry 50: 1267-1304, 1999.

10. Senilh V, Blechert S, Colin M, Guenard D, Picot F, Potier P and Varenne P: Mise en evidence de nouveaux analogues du taxol extraits de Taxus baccata. J Nat Prod 47: 131-137, 1984.

11. Shen Y, Chaturvedula VSP and Hung M: Taxane diterpenoids from the root bark of Taiwanese Yew Taxus mairei. J Chin Chem Soc 47: 1125-1130, 2000.

12. Hanson RL, Howell JM, Brzozowski DB, Sullivan SA, Patel RN and Szarkal J: Enzymic hydrolysis of 7-xylosyltaxanes by xylosidase from Moraxella sp. Biotechnol Appl Biochem 26: 153-158, 1997.

13. Fu Y, Zu Y, Li S, et al: Separation of 7-xylosyl-10-deacetylpaclitaxel and 10-deacetylbaccatin III from the remainder extracts free of paclitaxel using macroporous resins. J Chromatogr A 1177: 77-86, 2008.

14. Lataste H, Senith V, Wright M, Guénard D and Potier Pl: Relationships between the structures of taxol and baccatine III derivatives and their in vitro action on the disassembly of mammalian brain and physarum amoebal microtubules. Proc Natl Acad Sci USA 81: 4090-4094, 1984.

15. Kikuno N, Moriyama-Gonda N, Yoshino T, et al: Blockade of paclitaxel-induced thymidine phosphorylase expression can accelerate apoptosis in human prostate cancer cells. Cancer Res 64: 7526-7532, 2004.

16. Pineiro D, Martín ME, Guerra N, Salinas M and González VM: Calpain inhibition stimulates caspase-dependent apoptosis induced by taxol in NIH3T3 cells. Exp Cell Res 313: 369-379, 2007.

17. Shankai S, Chen X and Srivastava RK: Effects of sequential treatments with chemotherapeutic drugs followed by TRAIL on prostate cancer in vitro and in vivo. Prostate 62: 165-186, 2005.

18. Nimmanapall R, Perkins CL, Orlando M, O'Bryan E, Nguyen D and Bhalla KN: Enhances Apo-2 ligand/tumor necrosis factorrelated apoptosis-inducing ligand-induced apoptosis of prostate cancer cells by inducing death receptors 4 and 5 protein levels. Cancer Res 61: 759-763, 2001.

19. Muenchen HJ, Poncza PJ and Pienta KJ: Different docetaxelinduced apoptotic pathways are present in prostate cancer lines LNCaP and PC-3. Urology 58: 366-370, 2001.

20. Park SJ, Wu CH, Gordon JD, Zhong X, Emami A and Safa AR: Taxol induces caspase-10-dependent apoptosis. J Biol Chem 279: 51057-51067, 2004. 
21. Uzzo RG, Leavis P, Hatch W, Gabai VL, Dulin N, Zvartau N and Kolenko VM: Zinc inhibits nuclear factor- $\kappa \mathrm{B}$ activation and sensitizes prostate. Clin Cancer Res 8: 3579-3583, 2002.

22. Dong QG, Sclabas GM, Fujioka S, et al: The function of multiple IkappaB: NF- $\kappa \mathrm{B}$ complexes in the resistance of cancer cells to taxol-induced apoptosis. Oncogene 21: 6510-6519, 2002.

23. Parone PA, James D and Martinou JC: Mitochondria: regulating the inevitable. Biochimie 84: 105-111, 2002.

24. Panvichian R, Orth K, Day ML, Day KC, Pilat MJ and Pienta KJ: Paclitaxel-associated multimininucleation is permitted by the inhibition of caspase activation: a potential early step in drug resistance. Cancer Res 58: 4667-4672, 1998.
25. Liu QY and Stein CA: Taxol and estramustine-induced modulation of human prostate cancer cell apoptosis via alteration in Bcl- $\mathrm{X}_{\mathrm{L}}$ and bak expression. Clin Cancer Res 3: 2039-2046, 1997.

26. Lebedeva I, Rando R, Ojwang J, Cossum P and Stein CA: $\mathrm{Bcl}-\mathrm{X}_{\mathrm{L}}$ in prostate cancer cells: effects of overexpression and down-regulation on chemosensitivity. Cancer Res 60: 6052-6060, 2000.

27. Wang TH, Wang HS and Soong YK: Paclitaxel-induced cell death. Cancer 88: 2619-2628, 2000. 